\title{
CZECH NATIONAL STRATEGY OF DEVELOPMENT OF INTELLIGENT TRANSPORT SYSTEMS AND LINKED ACTIVITIES
}

\author{
Eva Gelová1* , Jan Mynařík², Jan Vlčinský33, Martin Bambušek", Zuzana Švédová5
}

\begin{abstract}
The article presents topical news on intelligent transport systems policy, strategy, and linked activities in the Czech Republic. It introduces historical background, relation to other documents, and current development in 2021. The Strategy of Development of Intelligent Transport Systems 2021-2027 with a View to 2050 (in force since January 2021) is the core document. The strategy is introduced by its context, methodology and structure of the content. Focus on coming years is included in this article, too: essential support for the ITS policy brings the online ITS Library (https://www.its-knihovna.cz), a knowledge database, described here with its certain parts and space for supportive tools. The tools enable to manage information on implementation progress selected progress indicators and monitoring of ITS data quality, expressed by data conformance testing and its publishing. The conclusion chapter gives a general overview on implementation of the Strategy and the ITS Library in the future.
\end{abstract}

Keywords intelligent transport systems, ITS, knowledge database, key performance indicators, data conformance, implementation

\section{INTRODUCTION}

Intelligent transport systems (ITS) use combination of information and communication technologies for information support, management and control optimisation in transport. "ITS enable transport to be better planned, organized and managed so that transport is sustainable, accessible, interoperable, safe and economical" (Czech Republic, 2021a). Intelligent transport systems for road, rail and inland waterway transport modes are anchored in the Czech legislation and national strategical documents.

At the beginning of preparation of the strategic plan for intelligent transport systems was the coming end of the previous strategic document, the Action plan for the development of intelligent transport systems (ITS) in the Czech Republic until 2020 (with a view to 2050) (further as AP ITS) (Czech Republic, 2015).

\footnotetext{
1 Transport Research Centre, Lisenska 33a, 63600 Brno. Czech Republic (all chapters)

* corresponding author, e-mail: eva.gelova@cdv.cz,

2 Transport Research Centre, Lisenska 33a, 63600 Brno. Czech Republic (chapter 6.3.1)

3 TamTam Research s.r.o, for Transport Research Centre, Lisenska 33a, 63600 Brno. Czech Republic (chapter 6.3.2)

4 Transport Research Centre, Lisenska 33a, 63600 Brno. Czech Republic (chapter 6.3.4)

5 Transport Research Centre, Lisenska 33a, 63600 Brno. Czech Republic (chapters 4 and 5)
} 


\section{LINKAGE TO OTHER STRATEGIC DOCUMENTS}

The Strategy of Development of Intelligent Transport Systems 2021-2027 with a View to 2050 (further as STR ITS 2021+) (Czech Republic, 2021a) shows continuing considerations of important linked and related strategic transport documents from previous and current periods.

\subsection{Linkage to Czech strategic documents}

The ITS services and the whole national ITS environment are incorporated into goals of the wider national Transport policy of the Czech Republic for a period of 2014-2020 (with a view to 2050) (Czech Republic, 2013). Transport policy has its linked documents on lower level. One of them is so called Transport Sector Strategies, last time updated in 2017, which is the medium-term transport infrastructure development plan with a long-term perspective. This viewpoint is to be continued also for the new period.

STR ITS 2021+ supports all three strategic goals of the national Transport policy of the Czech Republic for a period of 2021-27 (with a view to 2050) (Czech Republic, 2021b): sustainable mobility, territorial cohesion and society 4.0 in transport (Czech Republic, 2016b, 2017b).

Overview of all transport strategies, so called Strategic Map, is part of web pages of the Czech Ministry of Transport. (Czech Republic, 2020a)

"For the transport sector, the interconnection of individual levels - European, national, regional and local - is important. Transport policy reflects the objectives of European transport policy, but equally important is the link with the strategic documents of regions and large cities." (Czech Republic, 2021b)

As stated previously, for years after the AP ITS period was dedicated, it was needed to establish a new plan. In line with the up-to-date national methodology for development of public strategies, it was decided to call it as strategy. The results from the AP ITS period were analysed: the positive experience continues, and the weaker spots were listed and considered when planning.

Implementation plan of the Action plan for the development of intelligent transport systems (ITS) in the Czech Republic until 2020 (with a view to 2050) (Czech Republic, 2016a) (further as IP ITS) elaborated individual goals and measures of the AP ITS into specific implementation intentions, from which later arisen projects. IP ITS for years after 2021 is built on the new STR ITS 2021+, and the previous IP ITS. The IP ITS had its regular updates (Czech Republic, 2020b).

ITS intentions on a national level are included after an approbation process. Intentions of regions and cities were/are not part of the IP ITS; territorial self-governments have those activities in their competences. Also the air transport mode is not part of the ITS strategical planning; it has their own global visions.

Based on the IP ITS list of approbated intentions, an organizational, expert and financial project planning follows. IP ITS is a living document, which is continuously updated and supplemented on the basis of longterm and short-term planning and program selection of specific project plans, resp. projects to be financed. In time of its ratification, the original IP ITS begun at 66 project intentions. Since that time, the implementation plan has been expanded, after updates, to 97 approbated project intentions. That means about 50\% increase between years 2016 and 2020. Methodology of project intentions approbation for IP ITS is also impacted by mandatory reporting of any ICT investments on a national level. Content of the IP ITS is further described in 6.3 below.

\subsection{Linkage to European strategic documents}

The European Directive on the framework for the deployment of Intelligent Transport Systems in the field of road transport and for interfaces with other modes of transport, in the consolidated version (European Union, 2010) and the consequent later documents (European Union, 2013a, 2013b) and the directive (European Union, 2019a) are being followed also on the Czech national level. 
Further European directives, for all considered transport modes in the STR ITS 2021+, were carefully incorporated (European Union, 2005, 2012, 2016a, 2016b), including the trend of connected and automated transport in road, rail and waterborne modes (European Union, 2019d). There are also other two EU directives followed (European Union, 2019b, 2019c). A linked manuscript (European Union, 2020) is recommended to the reader's attention.

\section{CONTEXT OF THE STR ITS 2021+}

When the Czech Government approved the AP ITS in 2015, it was required to provide an evaluation of the implementation of the AP ITS by end of 2020 and to consider and propose if to continue with an update of the original AP ITS (Czech Republic, 2015) or a completely new document on ITS development for the period after 2020. The AP ITS with the described general needs of ITS development remains valid, too, for this new period.

In 2019, the Ministry of Transport decided to create a new document for the years after 2020. A procedure was adopted for its creation: to update the already set strategy, accordingly to current trends and follow up on. The strategy also incorporated conclusions of the 2018 (non-public) audit of the Supreme Audit Office. The STR ITS 2021+ demands a long-term cooperation of national actors and specifies requirements (legislative, standardization, financial) for supporting further ITS development. (Czech Republic, 2021a)

Linking of the strategic documents developed earlier and for the upcoming period is depicted in Figure 1. Also, a role of the below described ITS Library is specified, in the figure.

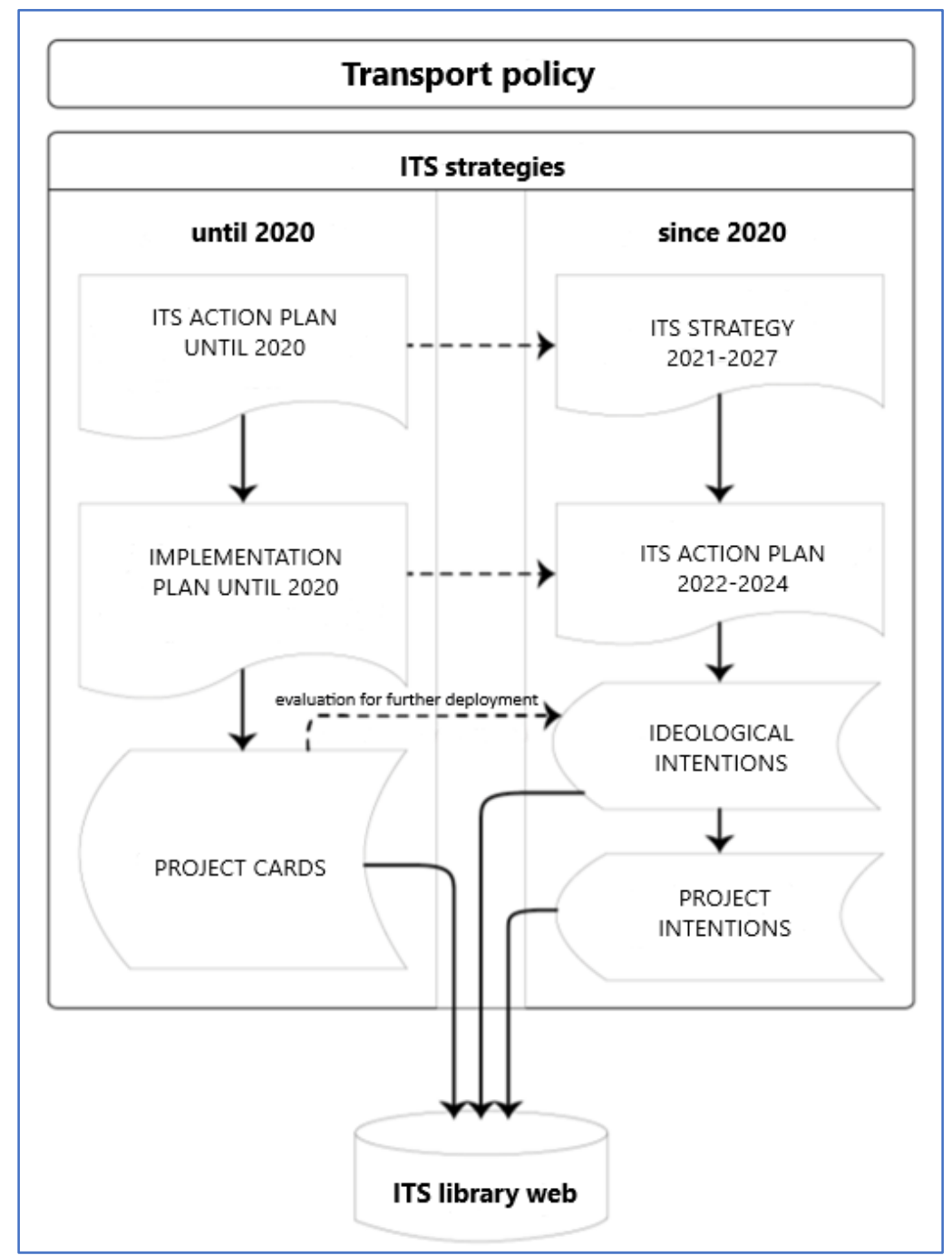

Fig. 1: Strategic environment of the Czech ITS and the linked ITS Library web; source: own (Czech Republic, 2021a) 


\section{METHODOLOGY}

The STR ITS 2021+ was completed after cooperation with interested stakeholders in ITS. Workshops and consultations were offered to administration and self-government bodies, the industry associations and academia, to gain their viewpoints, experience, new themes and ideas. There were seven working groups:

- BIM method and spatial information

- Data, digital level of the transport infrastructure and transmission networks

- Traffic and mobility organization and control

- Economy issues of ITS deployment

- Human factor

- Regulatory issues

- New trends

Working groups provided expert inputs for the STR ITS 2021+.

\section{STRUCTURE}

Four first chapters of the STR ITS 2021+ introduce background of both transport and ITS conditions, together with description of the STR ITS 2021+ preparation. Chapters five and six are as core of the document, defining the vision of ITS development to 2027: strategic goals, categories of measures, specific measures. All to be met during the period. Chapter seven sets up details of implementation procedures.

STR ITS 2021+ also includes three attachments:

- Annex 1: Maps for ITS priority implementation within the physical road infrastructure

- Annex 2: Evaluation of the AP ITS fulfilment until 2020

- Annex 3: Short introduction into ITS

The document sets up goals and priorities and explains how to support the ITS deployment in the considered future.

\subsection{General goal}

Vision of ITS development in the Czech Republic, the chapter 5, offers a vision on the ideal result of the ITS development in 2050 and general goal for 2027: "trouble-free safe and efficient travel and transportation, meeting the requirements of the times" when using a "digital level of the transport infrastructure“. Multimodality and partnership of involved subjects are thought as necessary. There is assumed connected, cooperative, and automated mobility (CCAM) in all modes and for both passengers and freight. Implementation of the latest intelligent mobility products and services into real operation is expected (Czech Republic, 2021a).

\subsection{Strategic goals}

Considering the AP ITS and the Strategic Plan for Further Development of National TIC (Czech Republic, 2017a), there were defined seven objectives as strategic goals. Except their description, also linguistic definition of the Key Performance Indicators (KPI) was linked at them. The seven strategic goals of the STR ITS 2021+ are:

1. Minimization of deaths and serious injuries due to traffic

2. Fully informed participants

3. Delay minimization

4. Optimization of financial costs 
5. Management and elimination of risks and their impacts

6. Single European Transport Area

7. Minimization of impacts on the environment and public health

\subsection{Specific measures}

ITS measures follow the previous seven strategic goals to more specific level and enable to focus on the vision of 2050 and the general goal for 2027. Totally sixteen ITS measures were proposed; they are divided into four groups. The expert working groups (see Methodology chapter above) gave the most valuable input to specify ITS measures based on current and future needs; at the end of this work, most of individual measures fulfil more of the strategic goals. The four groups of measures are following:
A. Knowledge Society and Digital Economy (5 measures)
B. Coordination of different modes of transport, based on quality and functional information services (3 measures)
C. Interconnection and integration of transport systems through ITS (3 measures)
D. Digital layer of transport infrastructure (5 measures)

\subsection{Subsequent activities}

The STR ITS 2021+ is being followed by implementation specification in the new Action Plan for the Strategy for the Development of Intelligent Transport Systems for the period 2022-2024 (further as AP ITS 2022+). The AP ITS 2022+ is to include ITS intentions and projects; those will be newly maintained and monitored via the ITS Library web (see chapter 6.3.3). AP ITS 2022+ is under revision procedure in time of completing this article. The final draft of the plan will be submitted by the Ministry of Transport to the Government by the end of the year 2021.

The plan is closely linked with funding resources, i. e. the ITS on a national level will be funded only if being part of the AP ITS 2022+, except brand new road network constructions, where ITS will be part of the construction budget. The funding framework for AP ITS 2022+ for the next period was already approved by the Czech Government in 2021.

\section{ITS LIBRARY}

The Ministry of Transport has decided to support knowledge service linked with the ITS deployment: the ITS Library (https://www.its-knihovna.cz/) web page that is continuously being developed. The ideological context of the web page is shown in the Figure 1 above.

The main goal is to offer knowledge important for understanding of ITS for general public, showing ITS functions, capabilities, and possible benefits. Main goal for public sector users is knowledge support that is necessary for decision making, i.e., good practices overview and transfer of knowledge.

The web also provides support for expert public, i. e. the ITS Tools (described in chapter 6.3 below) or links to national standardisation knowledge area, StandardLand web pages, and national regulation knowledge area, Quality policy of road network web pages.

\subsection{The web page content}

The web page offers general overview on activities in the area in the following sections:

- Highlight messages

- ITS

- Twitter links

- Library 
- Articles

- Actions

- ITS Tools

The library and the tools, the most important and sophisticated sections, are described below in individual chapters.

\subsection{Library}

The library offers three main parts: Themes, Documents and documentations, and Projects (see Figure 2).

Themes is the introducing part that shortly helps to understand basic naming, acronyms and functions of ITS. Chapters on ITS, C-ITS, Big Data, Smart Parking and Traffic Information give an overview, and offer links to related interesting web pages.

Documents and documentations content chapters of Legislation, Standards, Strategies and Concepts, and Others. Legislation of Czech, European and non-European documents. Standards area is divided into two parts with linkage to web sides of Road Quality Policy and Czech ITS Standardisation Committee as part of the European and global standardisation activities. Area of strategies offers documents of the CR, Europe and global, together with important reports and studies.

The Projects part offers overview of research and development projects: national, carried out in other countries and international with separate links to the most important of them: C-Roads and Crocodile 2.

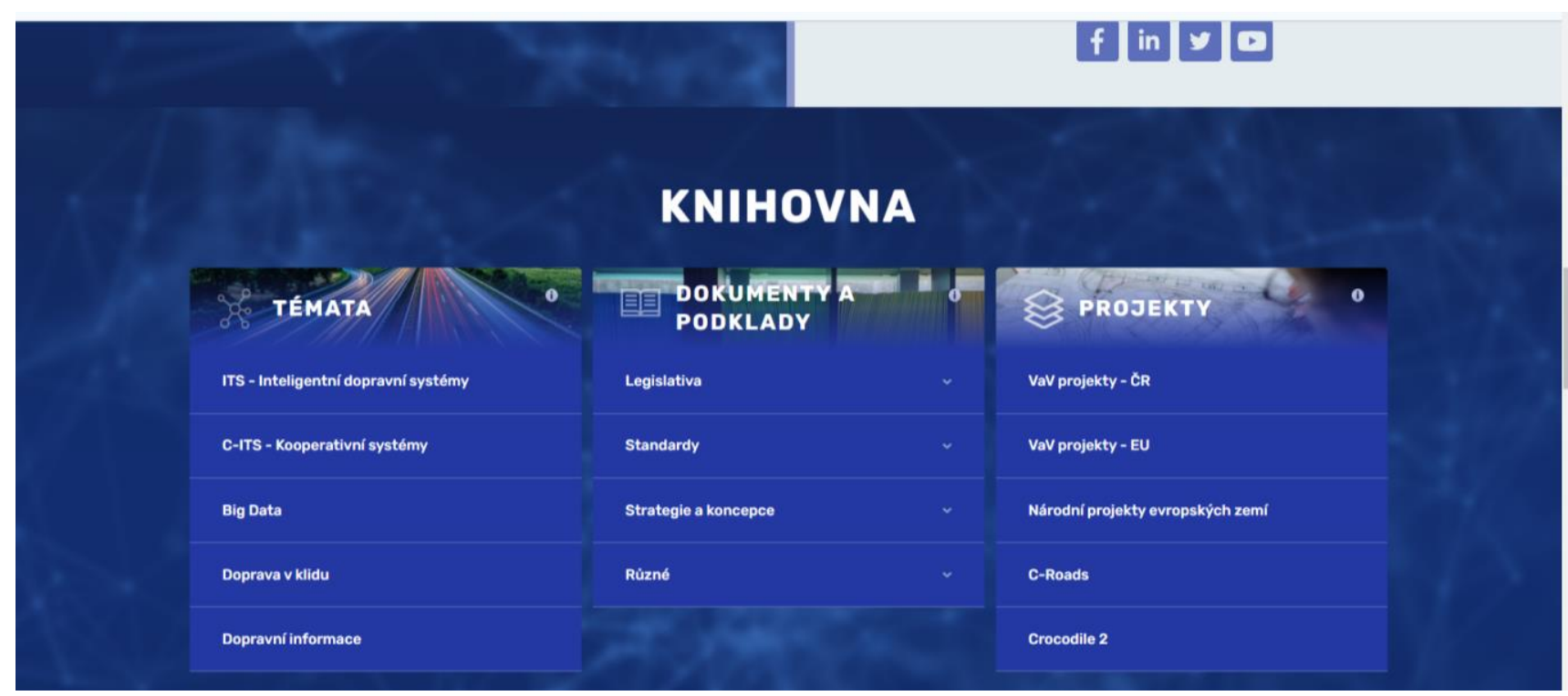

Fig. 2: Publication of the Library (in Czech: Knihovna) part of the ITS Library; source: own (ITS Library, web pages)

\subsection{ITS Tools}

The tools, as a non-public part, provide access for authorised persons only. This part (see Figure 3) offers:

- TEN-T KPI

- IDP Conform

- ITS implementation projects till 2020 (the status at the end of the AP ITS)

- ITS implementation projects since 2021 (the status since STR ITS 2021+) 


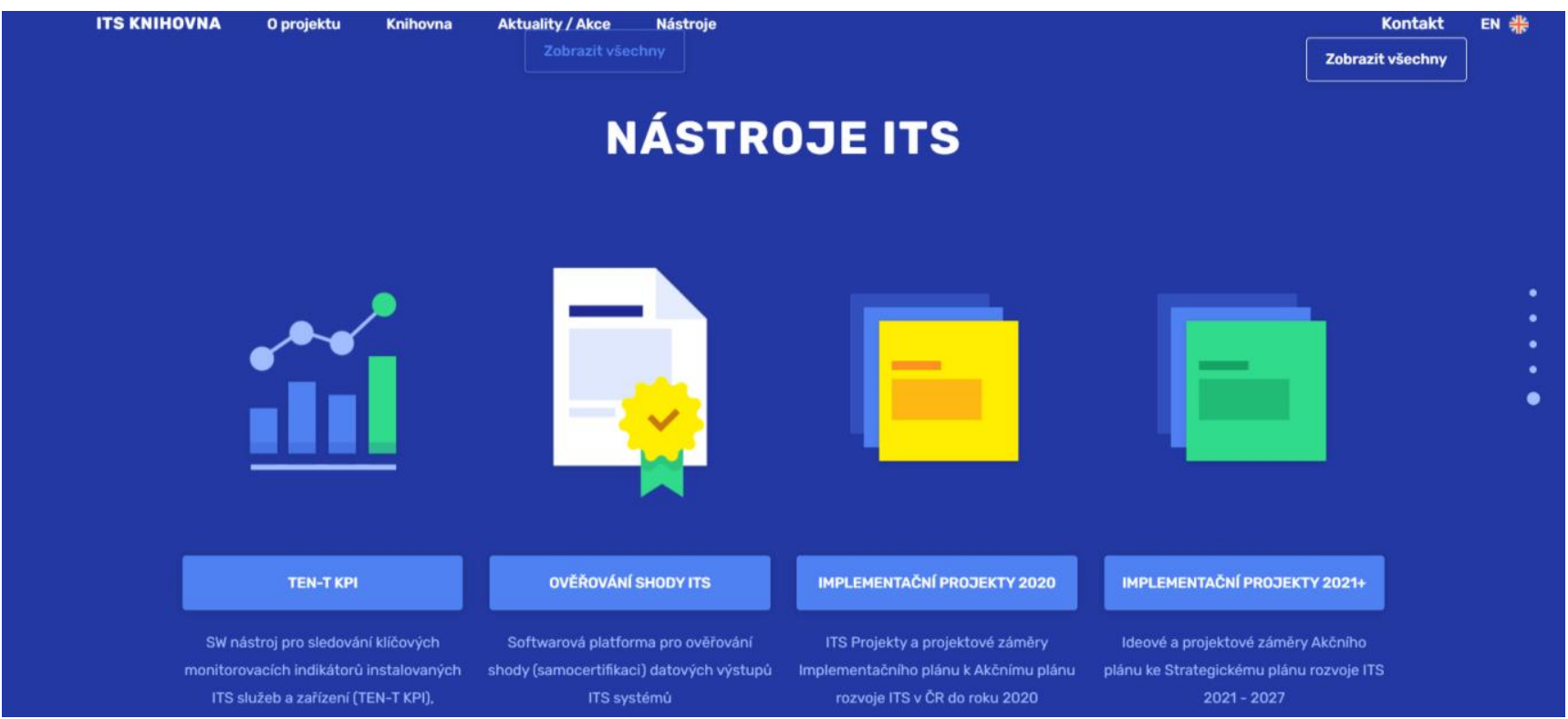

Fig. 3: Publication of the ITS tools (In Czech: Nástroje ITS) part of ITS Library; source: own (ITS Library, web pages)

\subsubsection{TEN-T KPI}

Key Performance Indicators (KPI) (AECOM Limited, 2014) for the Trans-European Transport Network (TEN-T) are to be used and provided in the annual national reports on ITS development; this demand is based on the EU ITS Directive (European Union, 2010).

Since the strategic goals have their linguistic KPI in the STR ITS 2021+, the numerical values of KPI are/will be defined for individual projects of the implementation plan.

The KPI tool within the ITS Library is used for monitoring of ITS deployment. It enables inputs on ITS implementation with details and location(s), visualisation of the data sets available within the application, and a semi-automated creation of the implementation reports. It gives a simple way to calculate the values of selected KPI and monitors efficiency of implemented ITS in the TEN-T. Access is limited: for authorized persons who work with the tool/application.

The KPI tool uses data sets provided by ŘSD (Czech Directorate of Roads and Motorways) (Ředitelství silnic a dálnic, web pages). The KPI are divided into two groups focused on:

\section{- Values of deployment}

- Values of benefit(s)

Depending on these two groups, the application adds a functionality that displays related data sets. It shows existing ITS, both any individual equipment and holistic systems, in maps. Data are being presented in a table format, too, in a preview and in a graph (see Figure 8 below).

- Deployment KPI show coverage of individual road sections, routes and the whole monitored network by various ITS technologies (i.e., coverage of the network by traffic counters).

- Benefit KPI display deployment impacts of the ITS elements in comparison with other data sets (for example with traffic intensities or accident rates).

The application also enables to compare the KPI in specific time periods with available data. 
An advanced software architecture was designed and is used, to be able to meet the set-up requirements (see Figure 4).

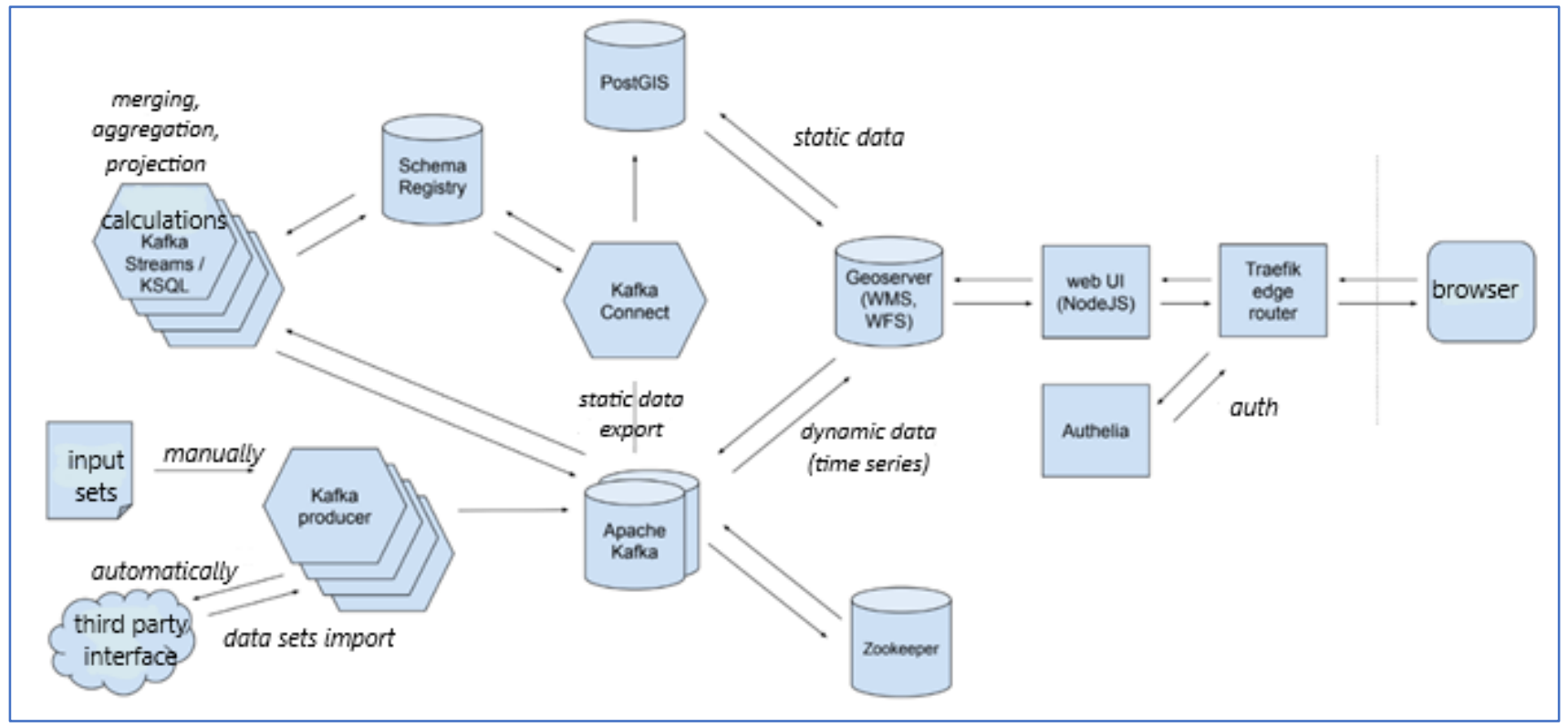

Fig. 4: TEN-T KPI: Scheme of the software architecture for the TEN-T KPI application; source: own (ITS Library, web pages)

The architecture enables receiving of source data sets in a form of individual imports or of regular updates. Source data sets are to be uploaded by authorised persons.

New data sets or data updates are currently being uploaded manually by the system developers, because a large part of critical data sets has not settled from the point of view of the data structure and format, yet.

The data are being uploaded into a time series repository (see the Apache Kafka repository in Figure 10), where they are permanently stored. The computing processes run above this repository. The data are being merged, aggregated, or projected, in the way that the targeted KPI (or an intermediate product) is calculated.

Depending on the data characters, the data either remain stored in the time series repository or are being uploaded onto a relational and GIS database. The GIS server queries to both repositories. The GIS server is being used by a presentation layer of the KPI application for making data available to users.

In terms of the software implementation, it was crucial to select suitable data attributes through which everything can be "linked". In publication of the deployment KPI, the equipment and the systems are as subjects. In presentation of the deployment KPI and the benefit KPI, the TMC (Traffic Management Control) segment as the smallest unit was used.

TMC segment is a road section between specific location points on location tables (LTs) for the monitored road network. Because of variability of the LTs in time, the GlobalNetwork segments are internally being used for the linking in the system since there is a minimum of variability just at them.

The figures below show various dashboards of the KPI tool with information on the Czech road and motorway network: the left bar offers four options to be selected and displayed: ITS equipment, ITS systems, deployment KPI and benefit KPI. 
Figure 5 displays a screen with a part of all ITS deployed, how it is monitored, visualised and published via the KPI application in the ITS Library.

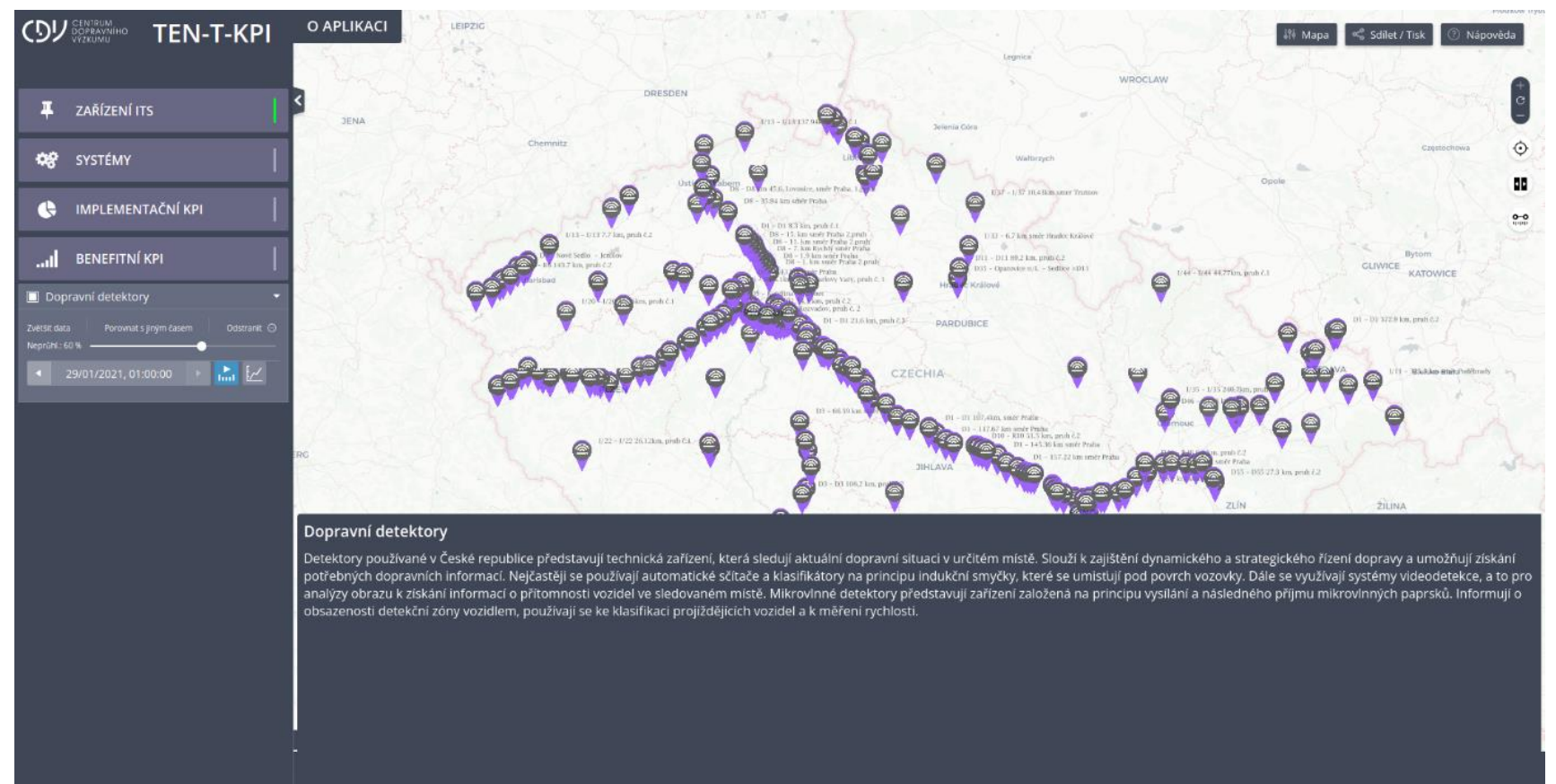

Fig. 5: TEN-T KPI: Dashboard with a general overview of the deployed ITS; source: own (ITS Library, web pages)

Among all ITS data, it is offered to demand a selected road section or route: as in Figure 6.

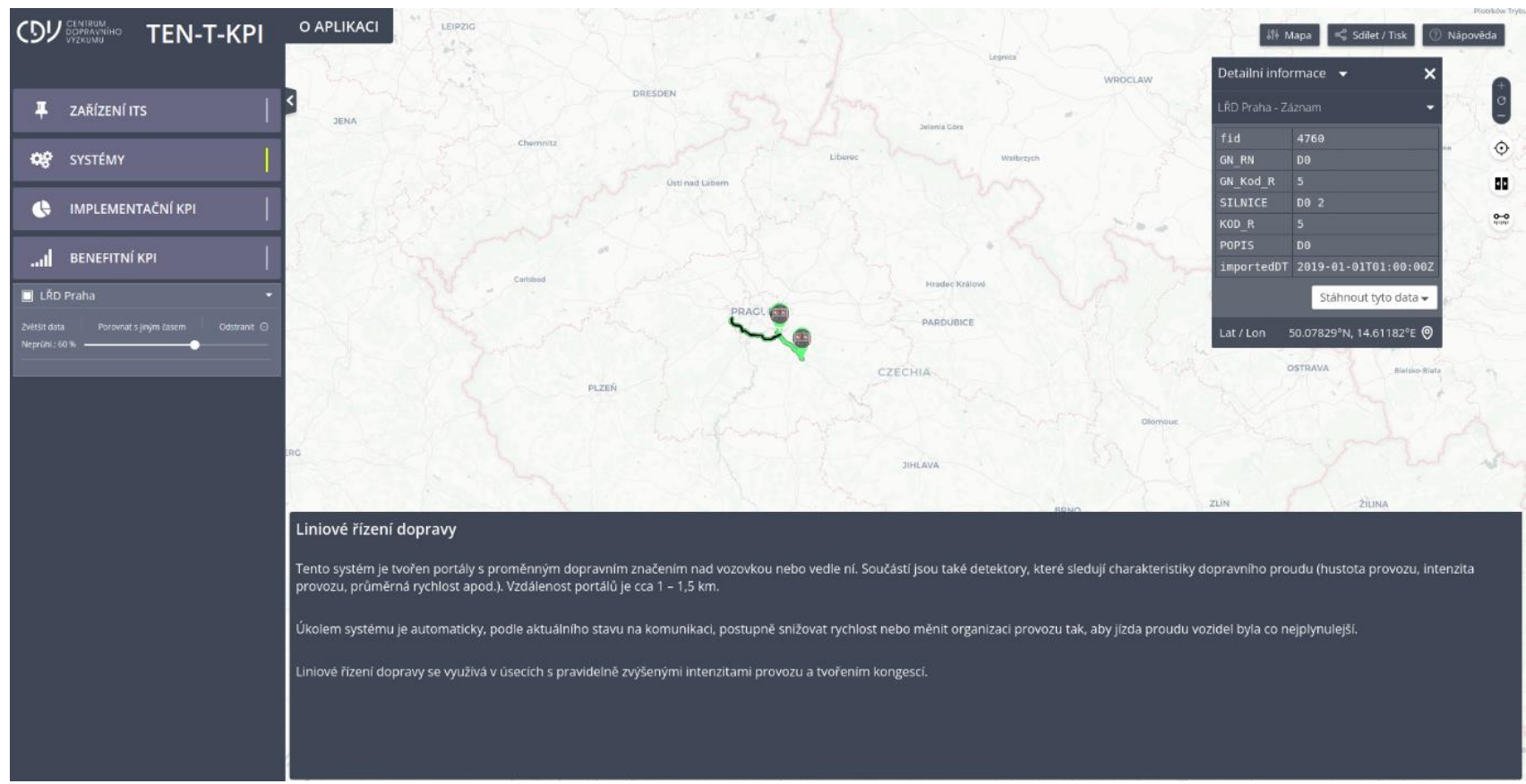

Fig. 6: TEN-T KPI: Example: Road Line Traffic Control (RLTC) at Prague outer ring road and D1 motorway (their crossing); source: own (ITS Library, web pages) 
It is also possible to use zooming to see details, there: see Figure 7.

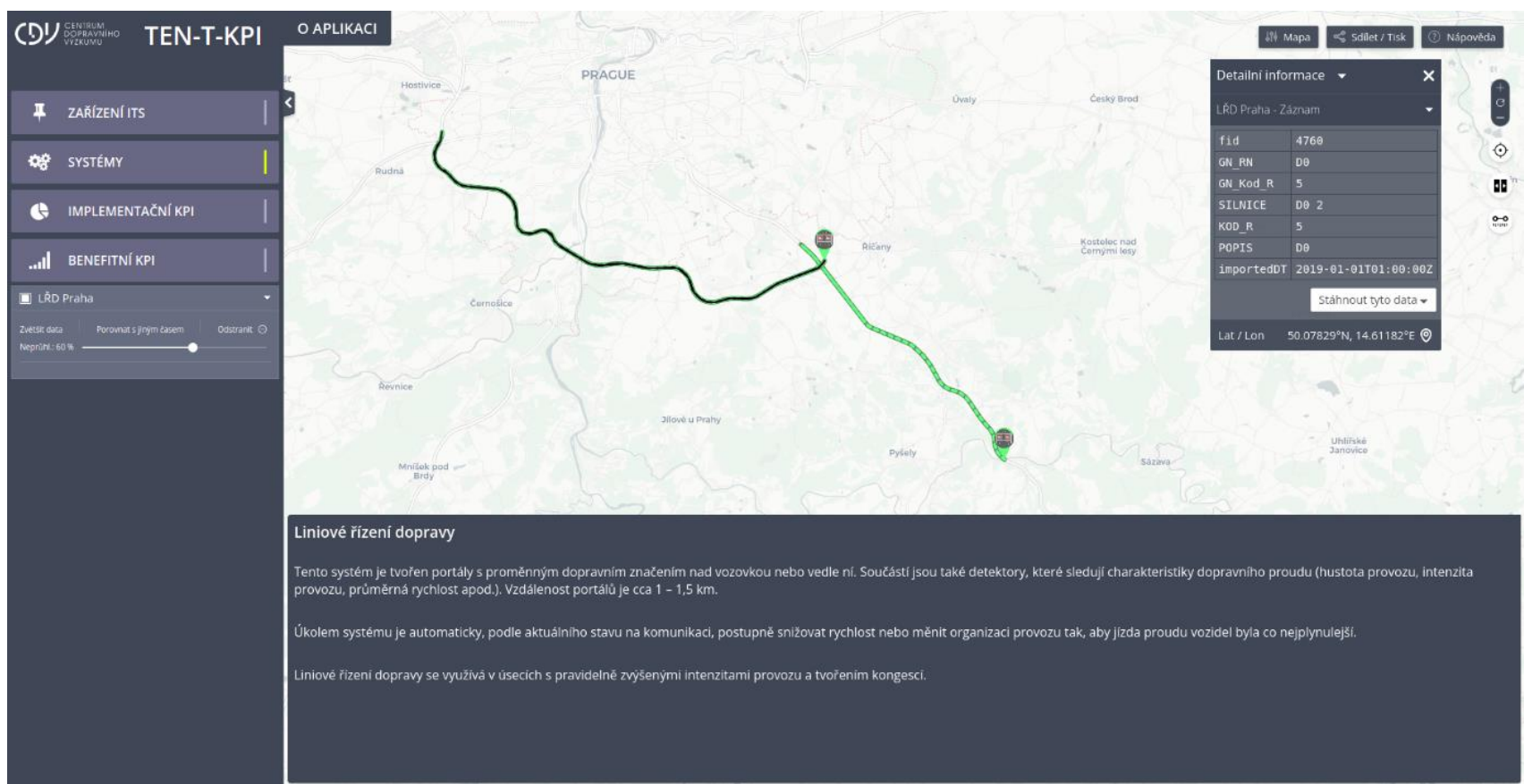

Fig. 7: TEN-T KPI: Example: Details on RLTC at Prague outer ring road and D1 motorway (their crossing); source: own (ITS Library, web pages)

If showing the selected deployment KPI, the dashboard displays deployment data in the following ma: see Figure 8.

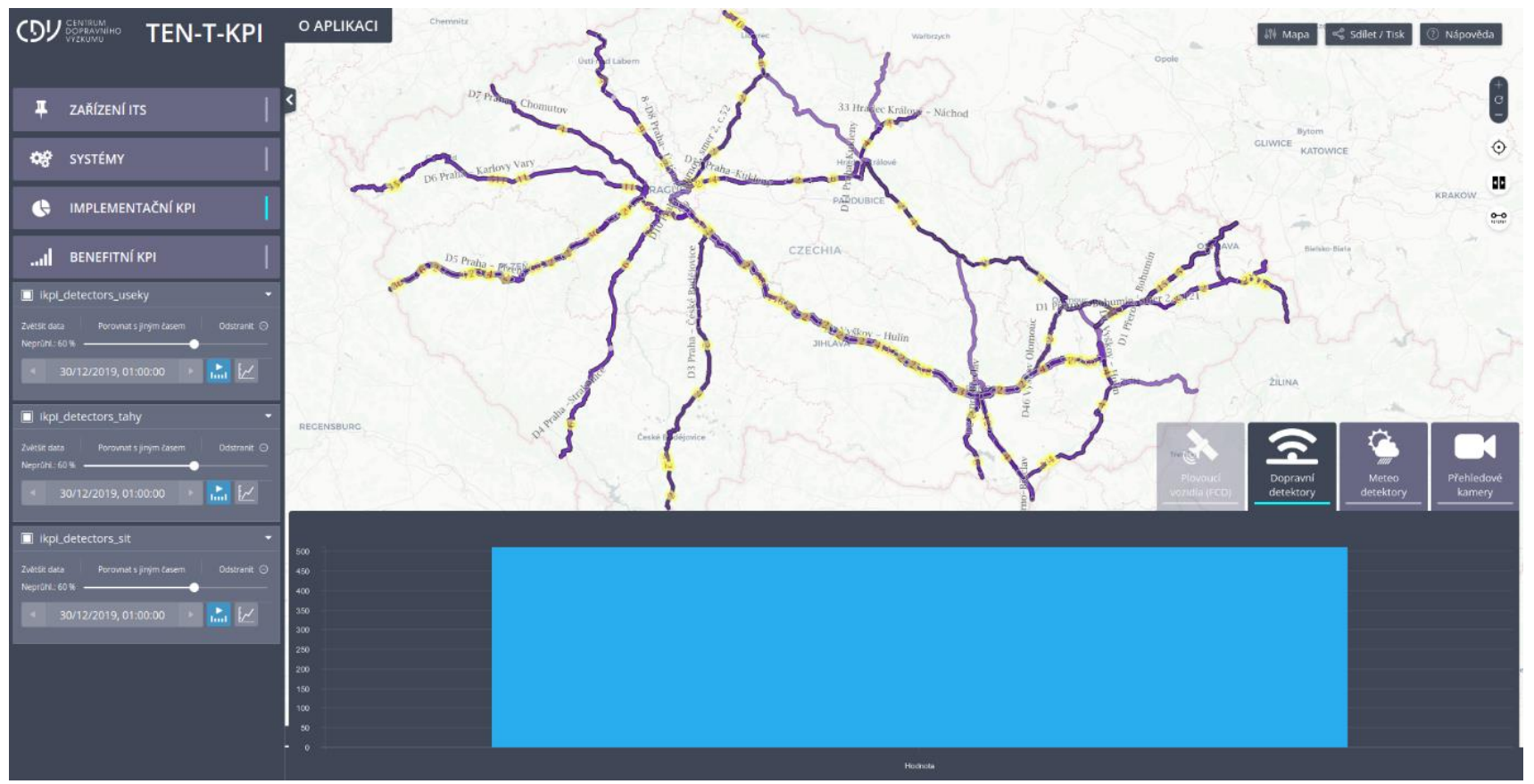

Fig. 8: TEN-T KPI: Example of the deployment KPI data dashboard; source: own (ITS Library, web pages) 
If showing the selected benefit KPI, the application publishes benefits data in the map: see Figure 9.

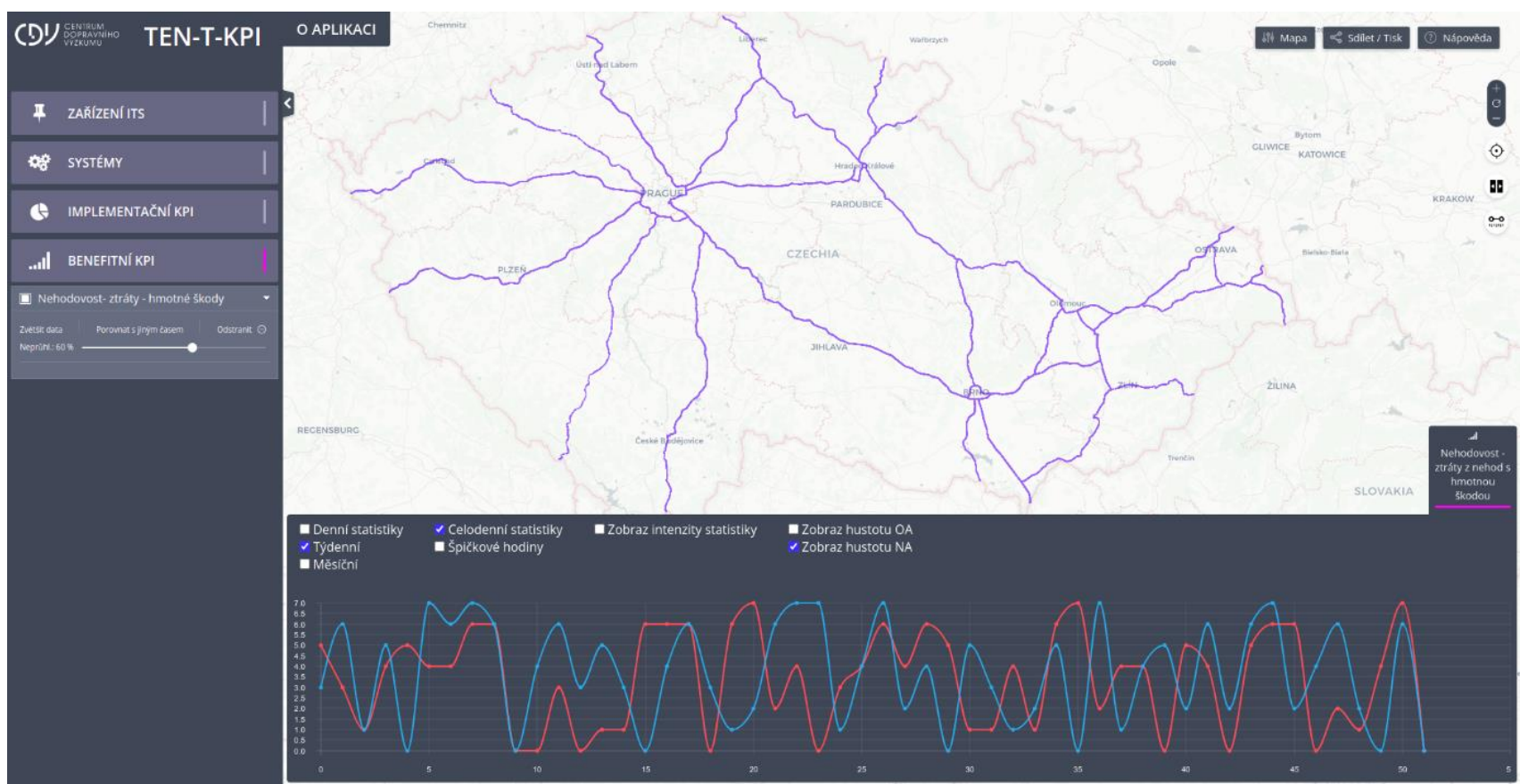

Fig. 9: TEN-T KPI: Selected benefit KPI dashboard; source: own (ITS Library, web pages)

The functionality of comparing of two time periods has the following visualisation output of the data: see Figure 10.

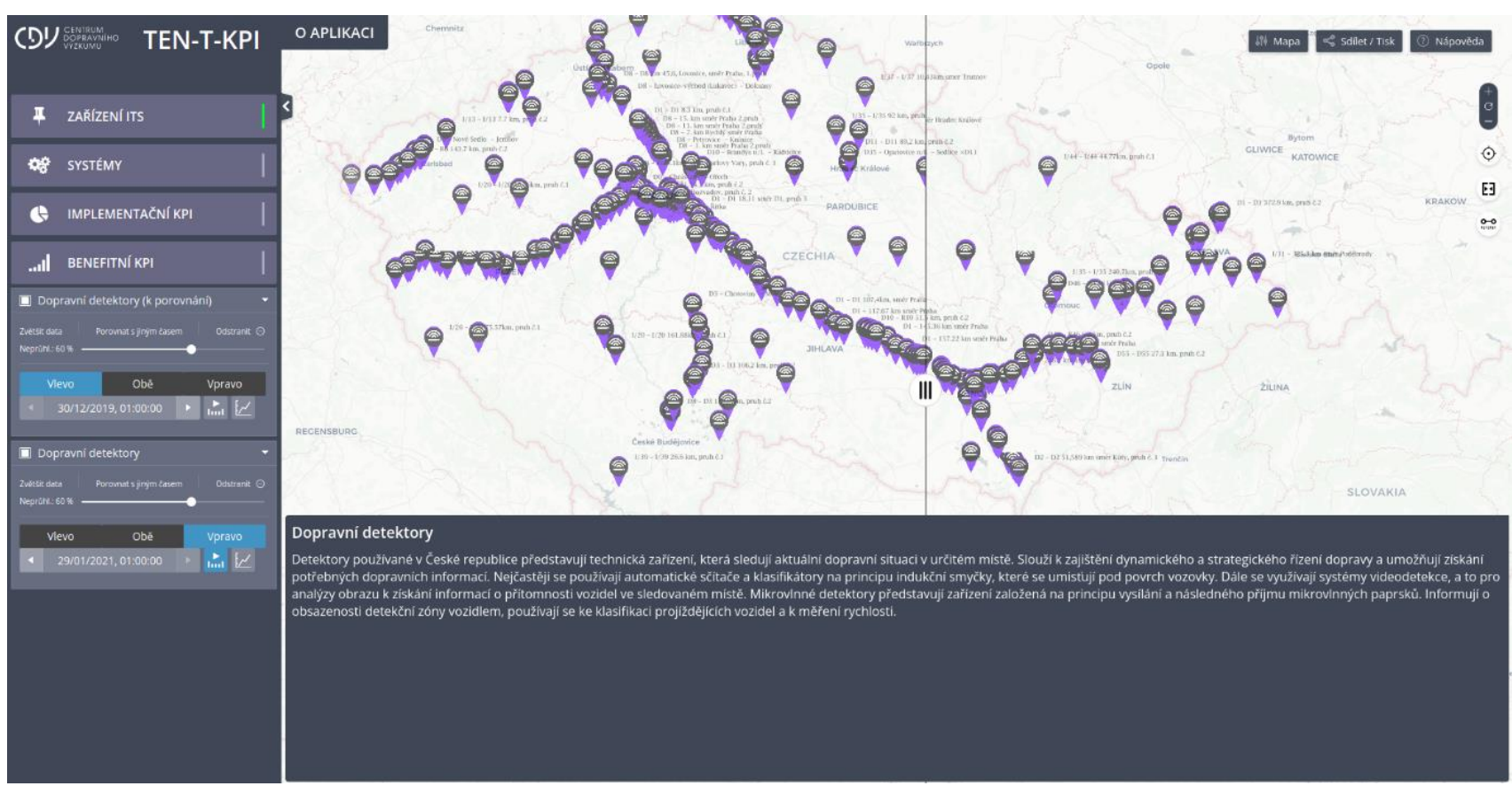

Fig. 10: TEN-T KPI: Two time periods comparison publication; source: own (ITS Library, web pages)

The KPI application already processes relatively large data and is also well prepared for forthcoming data sets updates.

\subsubsection{IDP Conform: ITS data publishing conformance testing system}

Another tool for experts is the ITS data publishing conformance testing system (IDP Conform in short). EC delegated regulations No 885/2013 (European Union, 2013a) and 886/2013 (European Union, 2013b) set up requirements on data providers publishing truck parking and safety related traffic information and require the establishment of a so-called Nominated Body which is supposed to evaluate fulfilling these 
requirements. These requirements are further extended by other delegated regulations to other types of data.

The IDP Conform shall help the Nominated body in two areas. First it brings up processes to find, evaluate, inform and support organizations, institutions and other subjects, who might be obliged to follow duties from the delegated regulations. Then, when data providers and sources are found, the tool provides technical means to collect, and archive published data (incl. documentation) and to evaluate and visualize its quantity and quality parameters.

Data providers are obliged to publish documentation of data formats, protocols and data sources provided, and the tool allows the evaluation of completeness and integrity of such documentation. Then, providers shall publish the data according to that documentation. The testing system consumes provided data, stores it, and validates conformance of it against provided schema definitions (mostly W3C XML schema). The IDP Conform gives access to each published message together with a validation report. Apart from structural conformance, quantitative parameters are evaluated such as number of published messages, number of particular records in those messages, size of published data and frequency of updates. All these parameters are visualized to provide an easy access to detailed information about how a particular data provider deals with providing its data.

To support defined processes, a CRM (Customer Relationship Management) of a Nominated Body shall be adapted to track communication with potential and registered data providers. Each provider is required to issue a declaration of conformance.

The technical part of the IDP Conform consists of modules KOA, SPOKK and GitLab.

The KOA module collects published data and stores them for later evaluation. Fixed set of protocols includes PUSH and PULL for plain HTTP as well as SOAP; the set can be extended if new protocols appear.

The SPOKK module verifies structural data validity for each published message and evaluates quality and quantity indicators.

GitLab is used to store documentation provided by data providers, to evaluate documentation completeness and integrity and to track resolution of detected issues.

In addition to the collection, archiving, testing, verification and certification, there is another important purpose of the system: to deliver structured data about providers, sources and the conformance testing as input for the annual national report. The Czech Ministry of Transport is due to deliver such a report towards the European Commission once a year.

Visualisation is done in Grafana. The "All providers - statistics" dashboard (see Figure 11) shows the most important quality and quantity indicators for all data sources.

The top horizontal block presents in graphical form the number of files received per hour for all data sources.

The second and third horizontal blocks show a table with statistics for all data sources. The former shows that for the whole period a given data source is collected (so it might cover years), the latter shows the same for the last three days to indicate whether the data source is currently working well or not.

The table shows the number of messages received; total number of records found in all received messages (record being relatively independent unit of information within the file); number of structural errors found by validating the files against relevant schema; average size of files received; time when the first and last file in given period were received; total duration of the period the files are considered, and average update period.

If the number of validation errors within the last three days is zero, the number is shown in green, otherwise it is red to highlight that given data source requires some attention and care. 


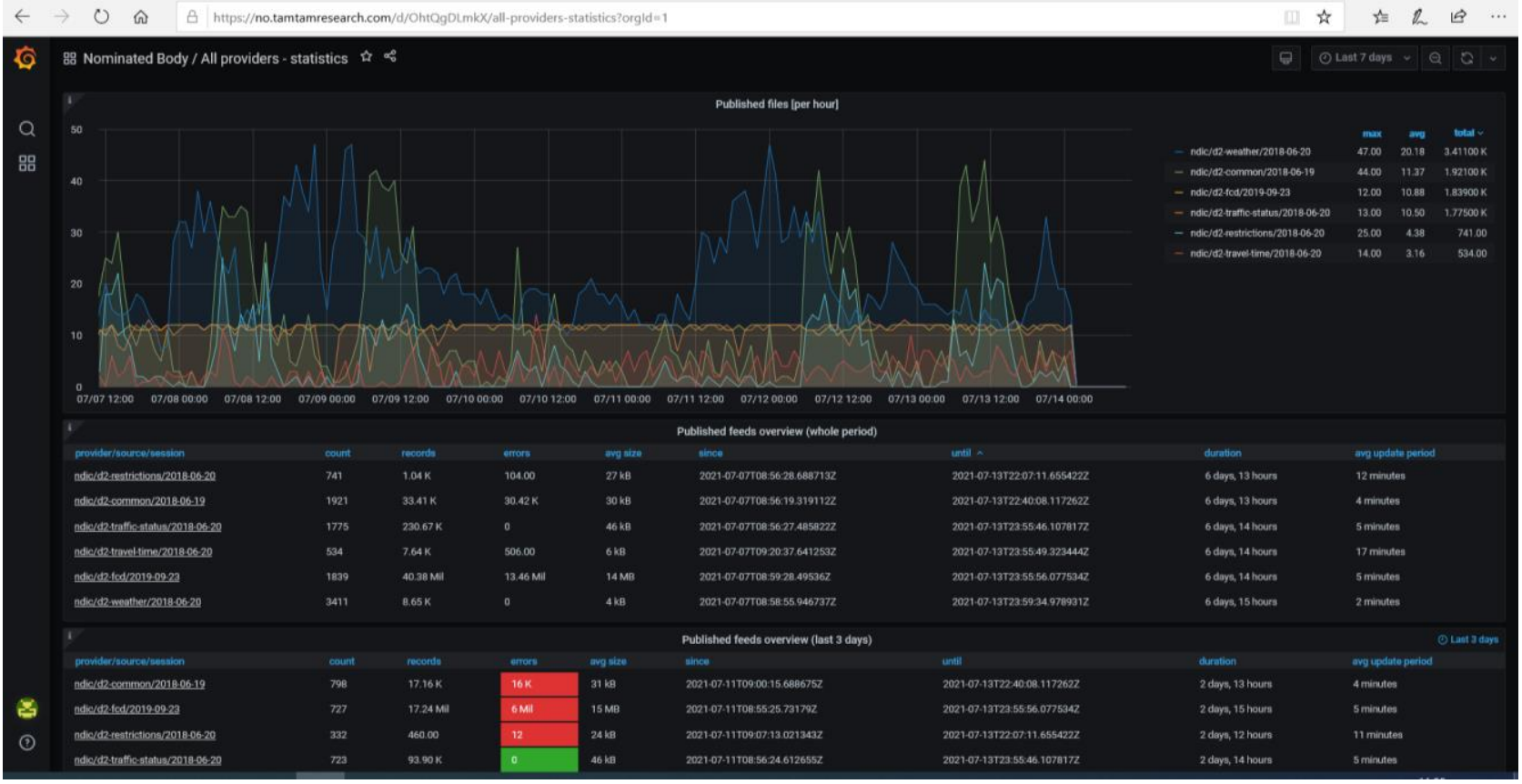

Fig. 11: IDP Conform: “All Providers Statistics” with provider/source/session specification; source: own (ITS Library, web pages; Vlčinský J., 2019)

The dashboard "Source details" (see Figure 12) provides a detailed overview for a particular data source (in our case a publication with travel times).

The table "Published files" lists all files received and apart from the number of validation errors, number of records, compression ratio and update periods; it also includes links to actual received files in raw form and to the validation report.

The charts present detailed information such as number of files received per hour, max size of the file in plain and compressed form, update period, number of validation errors, and number of records.

Last horizontal block "Invalid files" has the same structure as the "Published files" table described above; it includes only files which failed at validation.

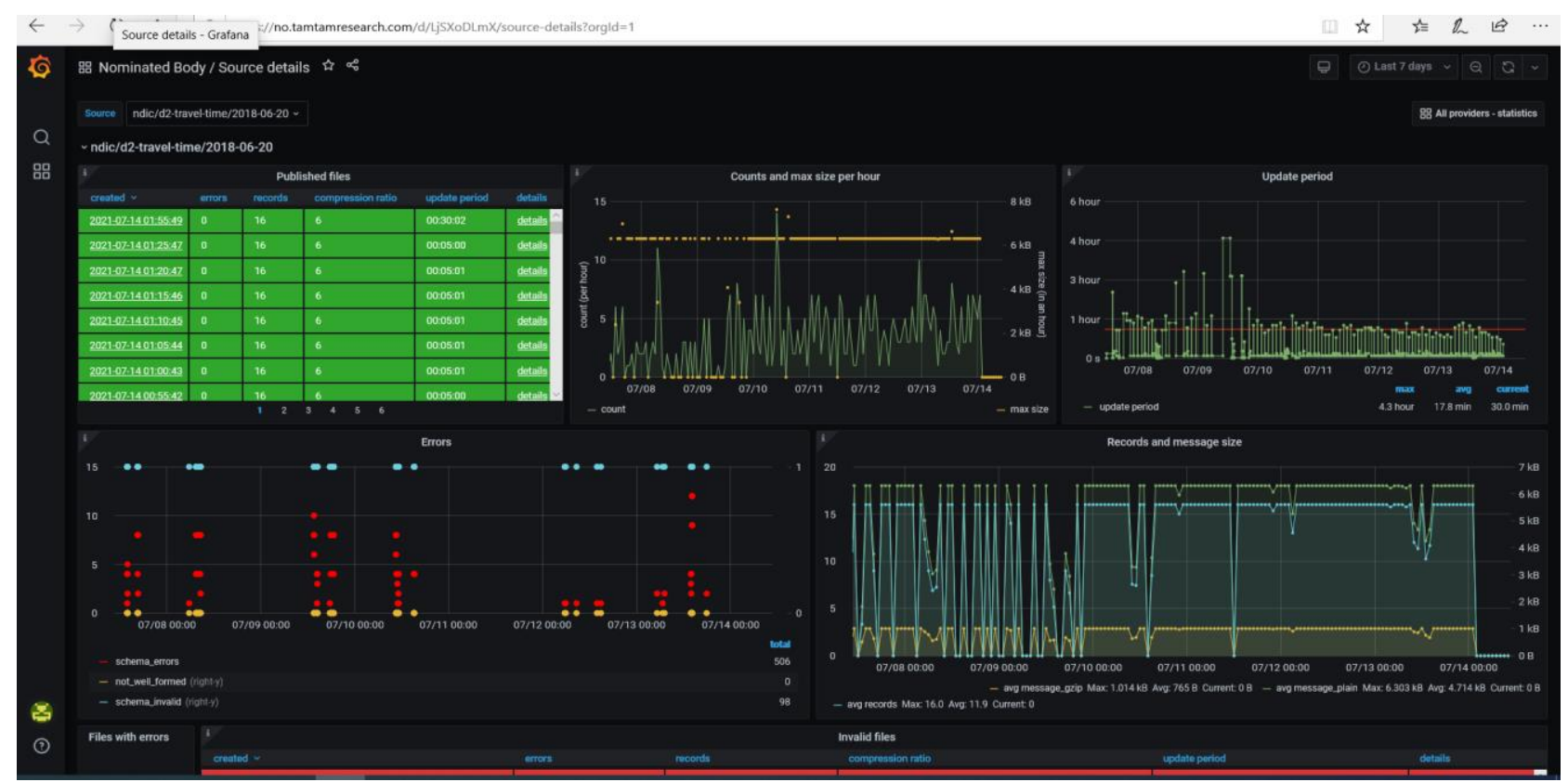

Fig. 12: IDP Conform: Example "Source Details: travel time"; source: own (ITS Library, web pages; Vlčinský J., 2019) 
Page "Session daily validation report" (see Figure 13) aggregates results of a data source validation for one day. The table lists all received files and provides links to the raw form of the given message. Bottom part of the page describes detailed validation issues.

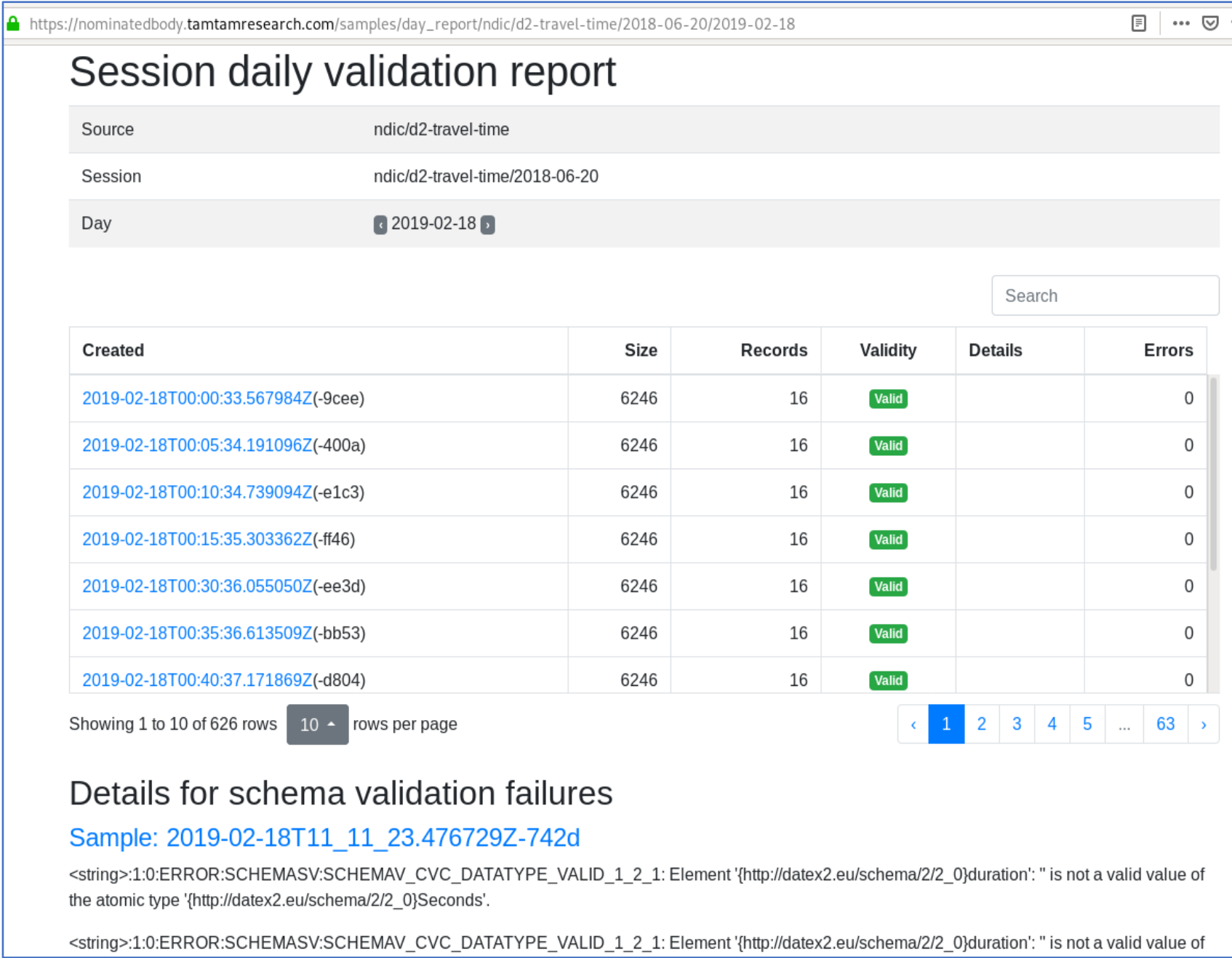

Fig. 13: IDP Conform: "Session daily validation report" with details; source: own (ITS Library, web pages; Vlčinský J., 2019)

Currently, six data sources are consumed from one provider, National Traffic Information Centre (NDIC), with the system being ready to scale well above tens of such sources when needed.

Current Czech infrastructure for publishing ITS data consists of the National Registry of Traffic Information (Traffic Information of NDIC), publishing documentation about current providers, sources, protocols and formats; Subscription Registry (https://mobilitydata.rsd.cz) managing subscriptions of consumers data published by NDIC (the Czech National Traffic Information Centre); and actual endpoints and services providing the data.

The IDP Conform naturally complements these subsystems by providing good insight into existing providers, relevant documentation and actually provided data. This allows the Czech Nominated Body to oversee the operation and quality of published data and to support data providers in improving the quality of their service.

\subsubsection{Czech ITS implementation management until 2020}

This part of the web serves as tool for recording of implementation projects with the status at the end of the AP ITS period (2020). It enables information searching, filtering, and exporting. The implementation 
intentions and projects have their cards (updated offline by their gestors, and then uploaded to the ITS Library by the administrator) with following details:

- ID

- Name

- Gestor of the project

- Description

- Detail information

- Schedule

- Launch

- Gestor of financing

- Budget

- Development in the last year

- Mode

- Strategic goal

- Specific goal

- Service

- Measure

- Group of measures

- Type of the measure

- State of the project

In this way, for example, it is easy to see how measures, specific and strategic goals are linked with implementation projects, how the project proceeds etc.

All projects were updated by their gestors each year until the project is completed or the activity is finished by another way (i.e., dividing or associating of items).

When searching for the projects and details of them, the web offers the following picture (see Figure 14).

\section{Karty záměrů a projektů v Implementačním plánu ITS (IP ITS)}

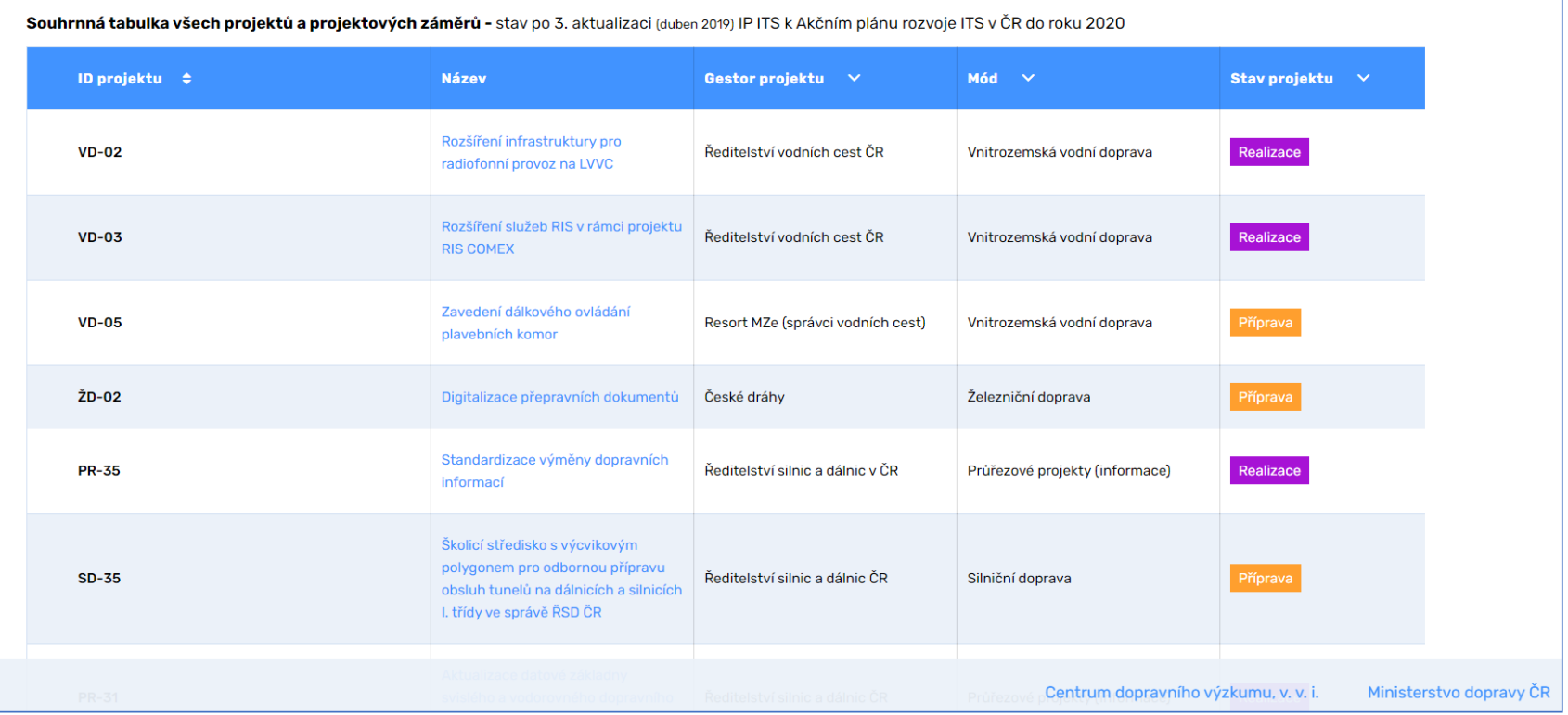

Fig. 14: Implementation management until 2020: Screen of the publication of the implementation list in the online database; source: own (ITS Library, web pages) 
After selection of one of the projects, all details mentioned previously are available, as shown in the following pictures (see Figures 15 and 16) of an example of a railway project: Diagnostic of running railway vehicles including control system.

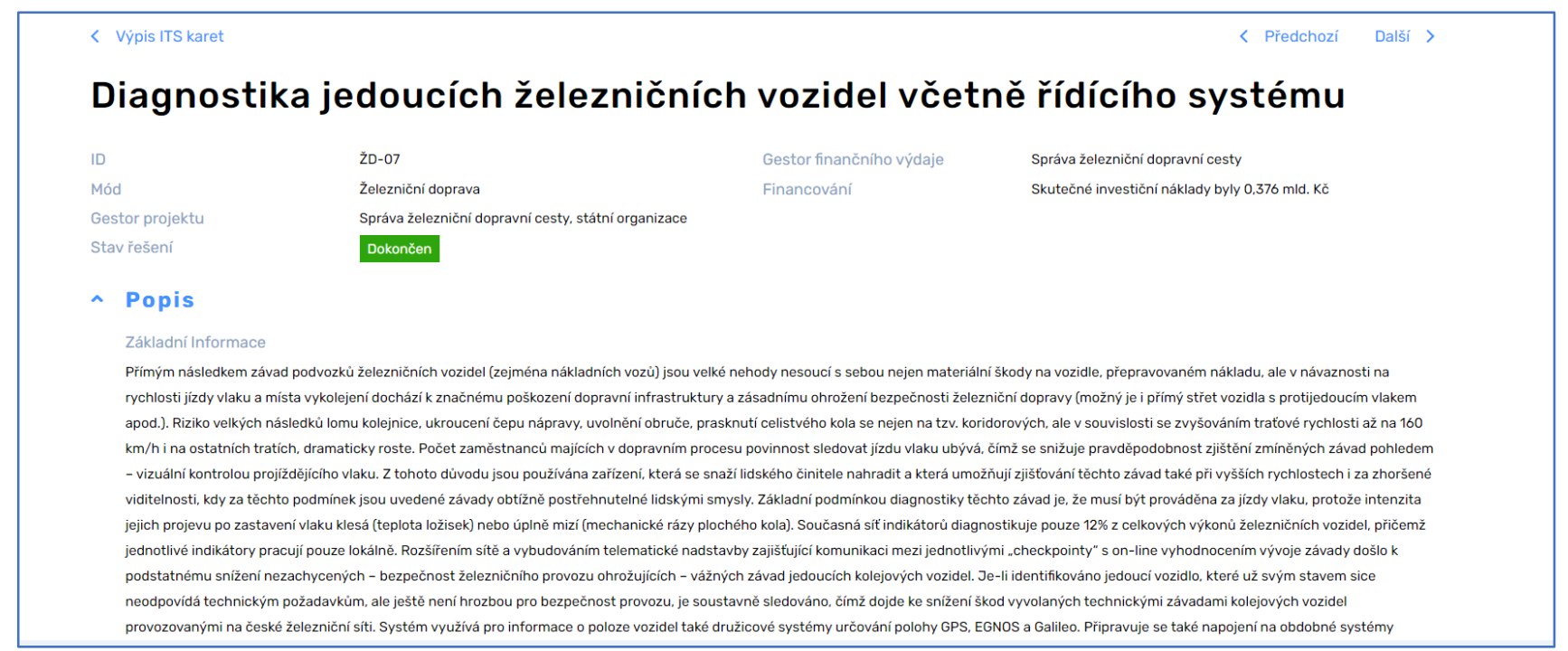

Fig. 15: Implementation management until 2020: Example of the implementation project publication: "Diagnostics of running railway vehicles including control system" (part 1); source: own (ITS Library, web pages)

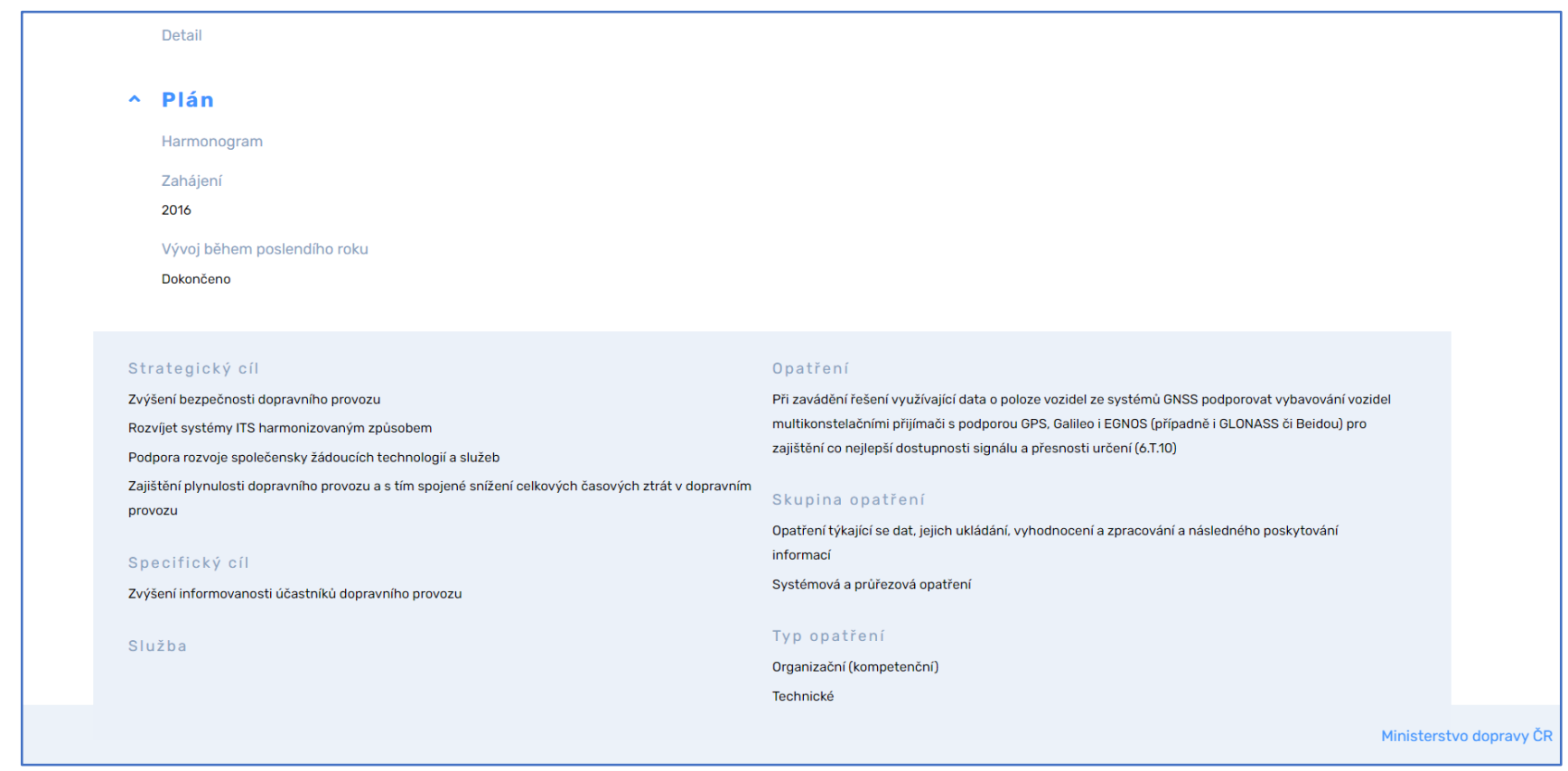

Fig. 16: Implementation management until 2020: Example of the implementation project publication: "Diagnostics of moving railway vehicles including a control system" (part 2); source: own (ITS Library, web pages)

Indeed, status changes history is available for any project in the database.

\subsubsection{Czech ITS implementation management since 2021}

The Coordinating Council for ITS of the Minister of Transport (KR-ITS) gained a new mandate, enabling to initiate creating of new ideological and project intentions. KR-ITS can give opinions and recommendations concerning the intentions, proposals for their solutions, and to monitor results of the individual implemented projects in practice.

For the monitoring target, a new procedure was proposed for creation and maintenance of so-called information card. The cards will be in use for both ideological intentions and projects intentions. These cards will be managed preferably in a digital form, directly via the ITS Library. 
This part of the ITS Library web pages for the new information cards is the subject of development in the year of 2021 and is to be completed. The tool enables the information cards management in time. It will accompany all project gestors, submitters and other actors in accordance with the project's whole life cycle and linked procedures, after 2021: from an implementation intention, its further specification to an implementation project plan and realization; an appointed gestor will gradually online complete the cards under his/her responsibility as part of the regular update.

The information cards continue the proven structure of information details as described previously. The lifecycle of the information cards is shown in the following Figure 17.

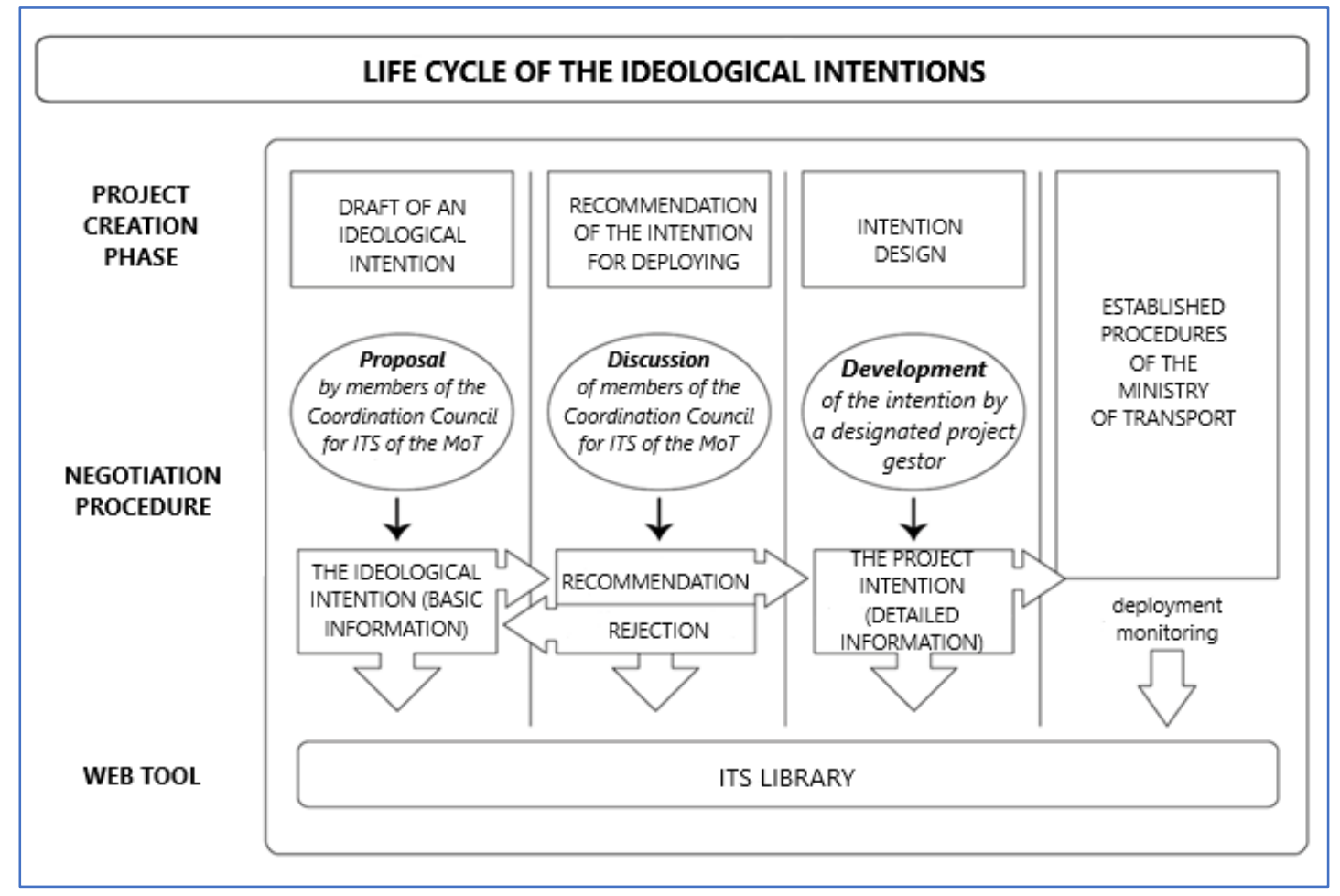

Fig. 17: Implementation management since 2020: Procedure of proposing, negotiations and evaluation of ideological intentions and project intentions for ITS; source: own (adjusted from Czech Republic, 2021a)

The process sustains of following stages, which are to be monitored via the its-library.cz:

- Draft creation of a new ideological intention (solution of a traffic problem) with basic information

- Proposal by KR-ITS

- The ideological proposal becomes an item for the implementation list

- Negotiation with discussions and assessment of an ideological intention by KR-ITS (contribution to goals and measures of the STR ITS 2021+)

- The ideological intention is assessed as:

- recommended for development to a project intention (intention gestor designated and design to be continued)

- rejected for a better proposal (new assessment later possible)

- Further design elaboration into a project intention (other detailed information, including KPI selection)

- Rejection/recommendation of a project intention through a set up common procedure of the Ministry of Transport

- If approved, then a subsequent deployment of the project intention

It is possible to create or update ideological intentions and project intentions in the catalogue of implementation in the ITS Library (see Figures 18 and 19). Monitoring of the progress, since the 
ideological intention till to the complete deployment, also runs via the ITS Library, as well as intentions evaluation.

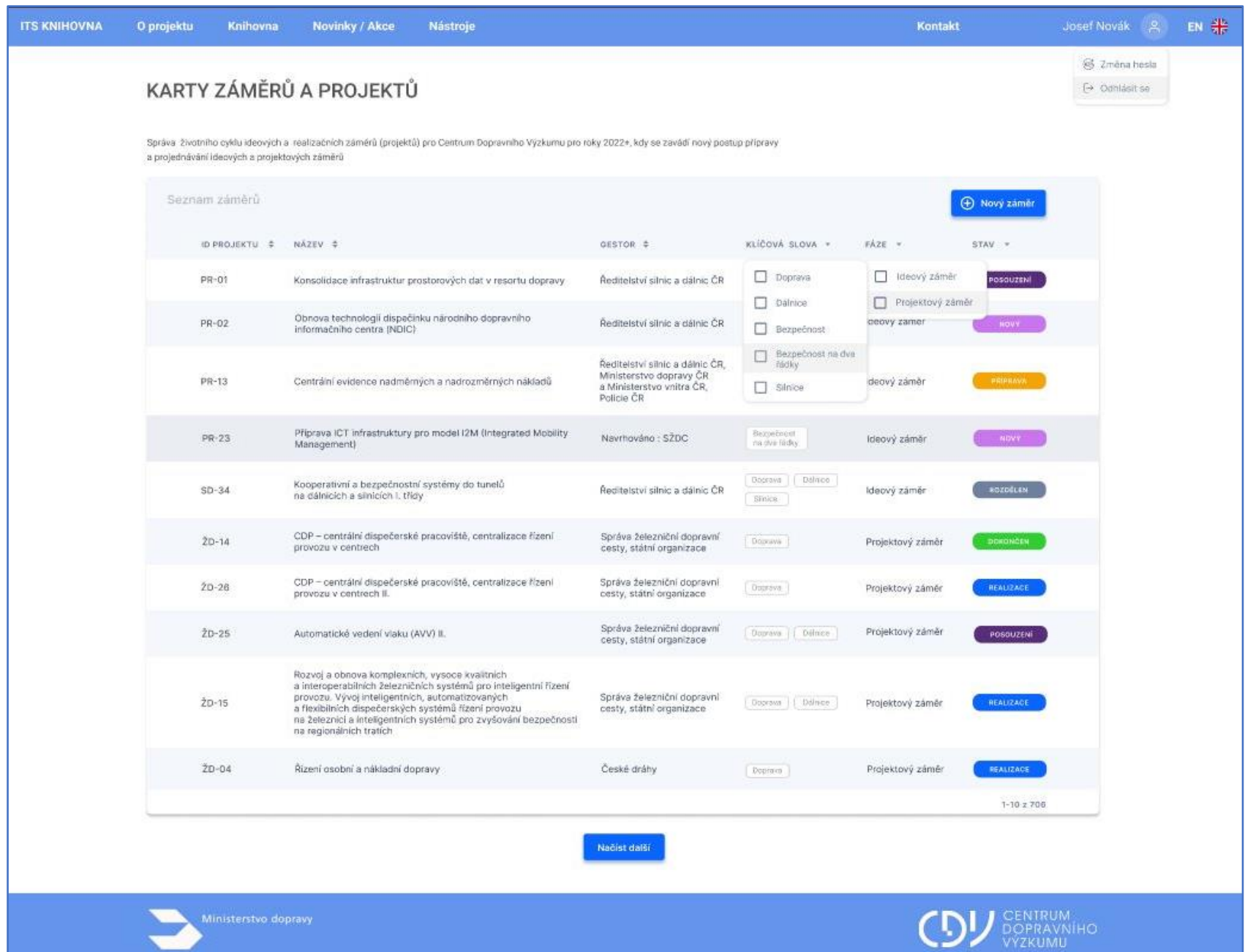

Fig 18: Implementation management since 2020: Catalogues of implementation (ideological intentions and project intentions); source: own (ITS Library, web pages)

\begin{tabular}{|c|c|c|}
\hline ITS KNIHOVNA & O projektu & Aktuality / Akce \\
\hline & \multicolumn{2}{|c|}{ Tvorba nového Ideového záměru } \\
\hline \multicolumn{2}{|r|}{ ID projektu } & cústo \\
\hline \multicolumn{2}{|r|}{ Název projektu } & text \\
\hline \multicolumn{2}{|r|}{ Navrhovatel } & vÿbér z ö́selmiku navrhovatel \\
\hline \multicolumn{2}{|r|}{ Druh dopravy } & vÿbèr z ciselniku druh dopravy \\
\hline \multicolumn{2}{|r|}{ Finanční náklady } & OBslo $[K C]$ \\
\hline \multicolumn{2}{|r|}{ Popis zámēru } & text \\
\hline \multicolumn{2}{|r|}{ Kličová slova } & text \\
\hline \multirow{2}{*}{\multicolumn{2}{|c|}{$\begin{array}{l}\text { Plán realizace / } \\
\text { Harmonogram }\end{array}$}} & \\
\hline & & lext/ dagram elap \\
\hline \multicolumn{2}{|r|}{ Vazba na cile } & caiselnik cile \\
\hline \multicolumn{2}{|r|}{ Vazba na opatření } & Öselonk gantien \\
\hline
\end{tabular}

Fig. 19: Implementation management since 2020: Creation of a new ideological intention (a part of); source: own (draft of ITS Library, web pages) 
After changes of update or a brand-new item is uploaded, following dashboard is available (see Figure 20).

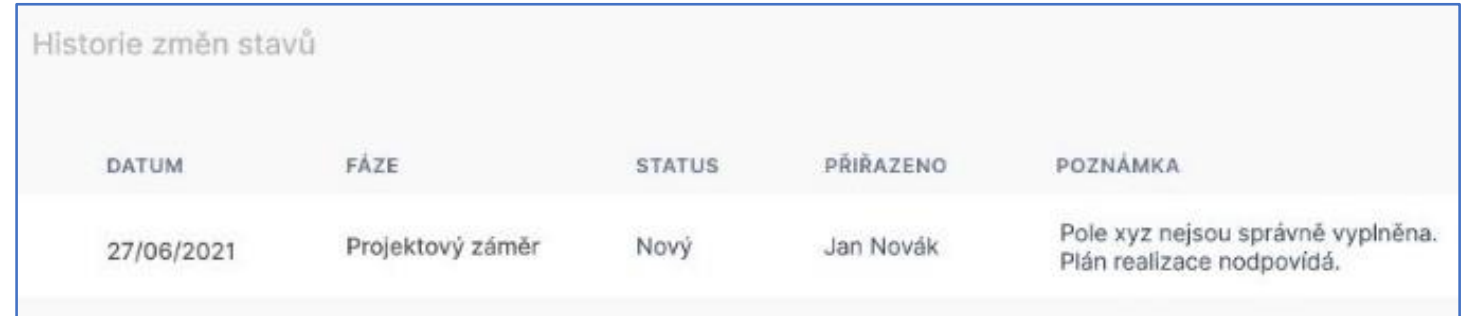

Fig. 20: Implementation management since 2020: History of the status changes; source: own (draft of ITS Library, web pages)

For 2021, the list of implementation proposals, to be continued or brand new, is known. Ideological intentions and project intentions to be newly integrated in 2021 were proposed before October 2021 and provided to their evaluation. The evaluation of the intentions has not been closed before completing of this article. The list of proven intentions and projects is not available, yet, but will be later published via the ITS Library web pages.

For the exchange of information on intentions, coordination meetings are being held. The meetings serve for coordination of the Ministry of Transport and departmental organizations. Agreed changes in intentions procedures are also planned to be reported by authorized persons directly to the ITS Library web pages, since the year of 2022 .

\section{CONCLUSIONS}

STR ITS 2021+ gives a starting point for the ITS development in next years and a vision till to 2050. The future work is defined within the general and specific goals, and measures in groups. STR ITS 2021+ is to be accompanied by the AP ITS 2020+ for completing the goals and measures of STR ITS 2021+ by specific ideological and project intentions.

As tool to promote and support the ITS community and implementation work, the ITS Library web pages were introduced as the knowledge database, to be regularly updated. The web also offers tools for creating mandatory annual reports (TEN-T key performance indicators monitoring system and ITS data publishing conformance testing system) and implementation updates (ITS implementation management).

Except the content maintenance (for CDV as web master) and use of tools (for authorized persons only), all other information is publicly available.

\section{Acknowledgements}

The preparation of the Czech Strategy of Development of Intelligent Transport Systems 2021-2027, with a view to 2050, was financially supported by the Ministry of Transport of the Czech Republic and was prepared in cooperation with Transport Research Centre. This strategy was approved on 4 January 2021.

This article was produced with the financial support of the Ministry of Transport within the programme of long-term conceptual development of research institutions.

Development works on software tools for TEN-T KPI monitoring, ITS data publishing conformance testing system (IDP Conform) and Implementation projects monitoring, and also of the web pages of ITS Library as a whole, were ordered and financed by the Ministry of Transport of the Czech Republic. It was provided by Transport Research Centre (Centrum dopravního výzkumu v.v.i.), in a close cooperation with the sub providers: TamTam Research s.r.o. for (Vlčinský J., 2019) and Bluesoft s.r.o. for software of (ITS Library, web pages).

The authors of the article thank further to Libor Krejčí and Štěpánka Doleželová for their comments and language consultation. 


\section{References}

Related Czech strategic documents, together with other important documents, are published for all transport modes via the ITS Library web page. [Online]. Available at: https://www.its-knihovna.cz/cz

Czech Republic. 2021a. Development Strategy of the intelligent transport systems 2021-2027 with a preview to 2050. (In Czech: Strategie rozvoje inteligentních dopravních systémů 2021-2027 s výhledem do roku 2050), of 4. 1. 2021. [Online]. Available at: https://www.its-knihovna.cz/cz/knihovnaaplikaci/dokumenty-a-podklady/strategie-a-koncepce/ap-its

Czech Republic. 2013. Transport Policy of the Czech Republic for the period of 2014-2020 (with a preview to 2050). (In Czech: Dopravní politika ČR pro období 2014-2020 (s výhledem do roku 2050)), of 12. 6. 2013. [Online]. Available at: https://www.databaze-strategie.cz/cz/md/strategie/dopravni-politika-crpro-obdobi-2014-2020-s-vyhledem-do-roku-2050

Czech Republic. 2021b. Transport Policy of the Czech Republic for the period of 2021-2027 with a preview to 2050. (In Czech: Dopravní politika ČR pro období 2021-2027 s výhledem do roku 2050), of 8. 3. 2021. [Online]. Available at: https://www.mdcr.cz/Dokumenty/Strategie/Dopravni-politika-CR-pro-obdobi2014-2020-s-vyhled

Czech Republic. 2020a. Map of strategies of the Czech Ministry of Transport. (In Czech: Strategická mapa Ministerstva dopravy). [Online]. Available at: the interactive version: https://www.databazestrategie.cz/czx/strategicke-mapy-ministerstva/strategicka-mapa-md

Czech Republic. 2015. Action Plan of the intelligent transport systems (ITS) development in the Czech Republic to 2020. (In Czech: Akční plán rozvoje inteligentních dopravních systémů (ITS) v ČR do roku 2020), of 15. 4. 2015. [Online]. Available at: https://www.databaze-strategie.cz/cz/md/strategie/akcniplan-rozvoje-inteligentnich-dopravnich-systemu-its-v-cr-do-roku-2020-s-vyhledem-do-roku-2050

Czech Republic. 2016a. Implementation Plan to of the intelligent transport systems (ITS) development in the Czech Republic to 2020 (with a view to 2050). (In Czech: Implementační plán k Akčnímu plánu rozvoje inteligentních dopravních systémů (ITS) v České republice do roku 2020 (s výhledem do roku 2050), of 15. 6. 2016

Czech Republic. 2020b. Implementation Plan to of the intelligent transport systems (ITS) development in the Czech Republic to 2020 (with a view to 2050), latest update of 2020 (In Czech: Implementační plán k Akčnímu plánu rozvoje inteligentních dopravních systémů (ITS) v České republice do roku 2020 (s výhledem do roku 2050), nejnovější aktualizace 2020.)

Czech Republic. 2017a. Strategic Plan for Further Development of National TIC with a View for 10 Years (In Czech: Strategický plán dalšího rozvoje JSDI/NDIC s výhledem na 10 let), of 16. 5. 2017. [Online]. Available at: https://www.rsd.cz

Czech Republic. 2016b. Industry 4.0 Initiative (In Czech: Iniciativa Průmysl 4.0), of 24. 8. 2016. [Online]. Available at: https://www.mpo.cz/assets/dokumenty/53723/64358/658713/priloha001.pdf

Czech Republic. 2017b. Society 4.0 Alliance (In Czech: Aliance Společnost 4.0), of 15. 2. 2017. [Online]. Available at:

https://www.databaze-strategie.cz/cz/urad-vlady/strategie/spolecnost-4-0-2017?typ=struktura

Related EU directives, decisions, regulations, communications, resolutions, opinions, working documents and reports, together with other important documents, are published for all transport modes via ITS Library web page. [Online]. Available at: https://www.its-knihovna.cz/cz/knihovna-aplikaci/dokumentya-podklady/legislativa/evropska

European Union. 2010. Directive 2010/40/EU of the European Parliament and of the Council of 7 July 2010 on the framework for the deployment of Intelligent Transport Systems in the field of road transport 
and for interfaces with other modes of transport, consolidated version. In: Official Journal of the European Union. [Online]. Available at:

https://eur-lex.europa.eu/legal-content/EN/ALL/?uri=CELEX\%3A32010L0040

European Union. 2005. Directive 2005/44/EC of the European Parliament and of the Council of 7 September 2005 on harmonised river information services (RIS) on inland waterways in the Community. In: Official Journal of the European Union. [Online]. Available at: https://eur-lex.europa.eu/legalcontent/EN/TXT/?qid=1591606873788\&uri=CELEX:32005L0044

European Union. 2012. Directive 2012/34/EU of the European Parliament and of the Council of 21 November 2012 establishing a single European railway area (recast), consolidated version. In: Official Journal of the European Union. [Online]. Available at: https://eur-lex.europa.eu/legalcontent/EN/TXT/?uri=celex\%3A32012L0034

European Union. 2013a. Commission Delegated Regulation (EU) No 885/2013 of 15 May 2013 supplementing ITS Directive 2010/40/EU of the European Parliament and of the Council with regard to the provision of information services for safe and secure parking places for trucks and commercial vehicles. [Online]. Available at:

https://eur-lex.europa.eu/legal-content/EN/TXT/?qid=1591628969212\&uri=CELEX\%3A32013R0885

European Union. 2013b. Commission Delegated Regulation (EU) No 886/2013 of 15 May 2013 supplementing Directive 2010/40/EU of the European Parliament and of the Council with regard to data and procedures for the provision, where possible, of road safety-related minimum universal traffic information free of charge to users. [Online]. Available at:

https://eur-lex.europa.eu/legal-content/EN/TXT/?qid=1591629008697\&uri=CELEX:32013R0886

European Union. 2016a. Directive (EU) 2016/797 of the European Parliament and of the Council of 11 May 2016 on the interoperability of the rail system within the European Union In: Official Journal of the European Union. [Online]. Available at:

https://eur-lex.europa.eu/legal-content/EN/TXT/?qid=1591606628533\&uri=CELEX\%3A32016L0797

European Union. 2019a. Directive (EU) 2019/520 of the European Parliament and of the Council of 19 March 2019 on the interoperability of electronic road toll systems and facilitating cross-border exchange of information on the failure to pay road fees in the Union. In: Official Journal of the European Union. [Online]. [Online]. Available at:

https://eur-lex.europa.eu/legal-content/en/ALL/?uri=CELEX:32019L0520

European Union. 2016b. Directive (EU) 2016/1629 of the European Parliament and of the Council of 14 September 2016 laying down technical requirements for inland waterway vessels, amending Directive 2009/100/EC and repealing Directive 2006/87/EC. In: Official Journal of the European Union. [Online]. Available at: https://eur-lex.europa.eu/legal-content/EN/TXT/?uri=CELEX\%3A32016L1629

European Union. 2019b. Directive (EU) 2019/1024 of the European Parliament and of the Council of 20 June 2019 on open data and the re-use of public sector information. In: Official Journal of the European Union. [Online]. Available at:

https://eur-lex.europa.eu/legal-content/EN/TXT/?qid=1591611043557\&uri=CELEX:32019L1024

European Union. 2019c. Directive (EU) 2019/770 of the European Parliament and of the Council of 20 May 2019 on certain aspects concerning contracts for the supply of digital content and digital services. In: Official Journal of the European Union. [Online]. Available at: https://eur-lex.europa.eu/legalcontent/EN/TXT/?qid=1591610977352\&uri=CELEX\%3A32019L0770 
AECOM Limited. 2014. Key performance indicators for intelligent transport systems. Final report. [Online]. Available at: https://ec.europa.eu/transport/sites/default/files/themes/its/studies/doc/itskpi-final report v7 4.pdf

European Union. 2019d. STRIA Roadmap on Connected and Automated Transport Road, Rail and Waterborne. [Online]. Available at:

https://trimis.ec.europa.eu/sites/default/files/roadmaps/stria roadmap 2019-

connected and automated transport.pdf

European Union. 2020. Shaping Europe's Digital Future. [Online]. Available at:

https://ec.europa.eu/info/sites/default/files/communication-shaping-europes-digital-future-

feb2020 en 4.pdf

ITS Library (web pages) (In Czech: ITS knihovna). ITS policy and knowledge database and tools. [Online]. Available at: https://www.its-knihovna.cz/

StandardLand (web pages). ITS knowledge database. [Online]. Available at:

https://www.standardland.cz/

Quality policy of road network (web pages). Road system knowledge database. (In Czech: Politika jakosti pozemních komunikací). [Online]. Available at: http://www.pjpk.cz/

Traffic Information of the Czech National TIC (NDIC). [Online]. Available at: http://registr.dopravniinfo.cz

Vlčinský J. TamTam Research s.r.o. for Centrum dopravního výzkumu, v.v.i. 2019. System for control collection, archiving and evaluation of provided data (IDP Conform) (In Czech: Systém pro kontrolní odběr, archivaci a vyhodnocení poskytovaných dat)

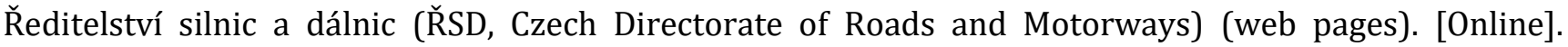
Available at: https://www.rsd.cz/wps/portal/

TamTam Research s.r.o. (web pages). [Online]. Available at: www.tamtamresearch.cz

Bluesoft s.r.o. (web pages). [Online]. Available at: https://www.bluesoft.cz/

Centrum dopravního výzkumu, v.v.i. (web pages). [Online]. Available at: https://www.cdv.cz/ 